\title{
GENRE ANALYSIS OF RESEARCH ABSTRACTS IN CENTRAL MINDANAO UNIVERSITY
}

\author{
Rene Marquez Bonifacio \\ Faculty in English, \\ Central Mindanao University, Philippines \\ (Email: renebonifacio@cmu.edu.ph)
}

Accepted date: 04-03-2018

Published date: 07-07-2019

To cite this document: Bonifacio. R. M. (2019). Genre Analysis of Research Abstracts in Central Mindanao University. International Journal of Education, Psychology and Counseling, 4(31). 225-236.

DOI: $10.35631 /$ IJEPC.4310019

\begin{abstract}
Research abstract provides a summary of a completed research article. This study aims to classify the pattern of the rhetorical moves, identify the obligatory and optional moves, and determine the linguistic features in the research abstracts of Central Mindanao University (CMU) undergraduate students. The study used content analysis and stratified random sampling. The corpora were the research abstracts written by the CMU undergraduate students in the Academic Year (AY) 2011-2015 using Genre-based Approach and Hyland's Framework for Abstract Analysis (2000). The study reveals that the M2-M3M4-M5 (purpose-method-product-conclusion) pattern obtained the highest number of occurrences with 159 or 50.96\%. Purpose (M2), method (M3), and product (M4) are considered as the obligatory moves because these moves appeared in all of the samples. Various linguistic features are also found. The variations of the rhetorical move patterns, diverse optional moves, and distinctive linguistic features imply that the CMU undergraduate students are unaware of the genre of writing research abstracts.
\end{abstract}

Keywords: CMU undergraduate theses research abstracts, Genre-based Approach, Hyland's Framework for Abstract Analysis (2000)

\section{Introduction}

Research abstract is one of the components of a research article that presents a brief overview of a completed research (Indiana University, 2010). It includes the background, objectives, methods, results, and conclusions of a research study (Swales \& Feak, 2009). It is vital for researchers who would like to present and publish their research papers (The University of Melbourne, n.d.) because reviewers usually evaluate the research abstracts first. Researchers who study research abstracts use genre analysis to evaluate the said text-type.

Genre analysis is a component of the genre-based approach that highlights the writing conventions of a specific genre (Bhatia, 1993). It investigates the rhetorical move information and the logical arrangement of each move in every text-type (Osman, 2004). 
One of the advocates of genre analysis is Ken Hyland. Ken Hyland designs five rhetorical moves in writing a research abstract, namely: introduction (M1), purpose (M2), method (M3), product (M4), and conclusion (M5). The introduction presents the study's overview; the purpose shows the objectives of the study; the method provides the step-by-step procedure on how the study is conducted; the product contains the results of the study; and the conclusion specifies the implications of the study (Hyland, 2000). In short, the genre of writing a research abstract is introduction-purpose-method-product-conclusion or M1-M2-M3-M4-M5 (Hyland, 2000).

Many researchers have analyzed the research abstracts' genre. For instance, Yun (2011) employed Hyland's Framework for Abstract Analysis (2000) in studying how linguistics and chemistry researchers write their research abstracts in English and Chinese. Yun (2011) found that linguistics researchers who used English and Chinese employed purpose-methodproduct-conclusion (M2-M3-M4-M5) pattern, chemistry researchers who used English followed purpose-method (M2-M3) pattern, while chemistry researchers who employed Chinese used method-product (M3-M4) pattern. The study concluded that the research abstracts in English and Chinese differ in various features.

Also, Fan-ping (2011) examined 90 research article abstracts in TESOL Quarterly, Applied Linguistics, and Language Learning using Swales and Feak's (2004) Framework for Move Analysis. The results revealed that most writers used aim-method-results-conclusion (M2M3-M4-M5) pattern. The study also conveyed that the background (M1) was an optional move, while the rest of the four moves were obligatory moves. They generally used the present tense in writing the background (M1), aim (M2), and conclusion (M5), while past tense for method (M3) and results (M4). The study concluded that the three journals differ in various structures.

Many students are competent in conducting research, but some are poor in writing their manuscript. Many students are adept in writing their research, but some are unaware of the rhetorical moves and how to coherently write the information in their paper, including the linguistic features that they need to use. Furthermore, some students neglect the conventions of writing research articles, specifically research abstracts.

This study aims to bridge this gap as it evaluates how the undergraduate students of Central Mindanao University (CMU) write their research abstracts in the Academic Year (AY) 20112015 using Genre-based Approach and Hyland's Framework for Abstract Analysis (2000). Specifically, the study aims to classify the pattern of the rhetorical moves employed in the research abstracts of CMU undergraduate theses; identify the obligatory and optional moves in the research abstracts of CMU undergraduate theses; and determine the linguistic features, specifically the tense of the verb, the voice of the verb, and the sentence structure, in the research abstracts of CMU undergraduate theses.

\section{Objectives of the Study}

The study aims to evaluate the research abstracts written by the undergraduate students of Central Mindanao University (CMU) in the Academic Year (AY) 2011-2015 using Genrebased Approach and Hyland's Framework for Abstract Analysis (2000).

Specifically, the study aims to:

1. classify the pattern of the rhetorical moves employed in the research abstracts of CMU undergraduate theses; 
2. identify the obligatory and optional moves in the research abstracts of CMU undergraduate theses; and

3. determine the linguistic features used by the researchers regarding the following:
a. tense of the verb
b. voice of the verb
c. sentence structure

\section{Literature Review}

\section{Background of Research Abstract}

Abstract comes from the "Latin abstractum, which means a condensed form of a longer piece of writing" (The University of Adelaide, 2009). A research abstract provides a concise and straightforward representation of the whole research article (Indiana University, 2010). Furthermore, it usually contains about 250 words (The University of Melbourne, n.d.).

Research abstracts are mostly used if a researcher wants to submit his/her study for journal publications, conference presentations, research grant competitions, and thesis completion (The University of Melbourne, n.d.).

Research abstracts contain the purpose, methodology, results, and conclusions of the study (Bhatia, 1993). Swales and Feak (2009) cite that a research abstract includes the background, aims, methods, results, and conclusions of the study, with the background as an additional rhetorical move.

\section{Background of Genre-based Approach}

Sidaway (2006) explains that Genre-based Approach came from MAK Halliday's Systemic Functional School of Linguistics in the 1960s and 1970s and it focuses on the particular uses of language for specific social situations. Hyon (1996) cites that it came from English for Specific Purposes (ESP), Australian Genre-based Educational Linguistics, and North American New Rhetoric studies.

Hyland (2008) discusses that Genre-based Approach is mostly used in writing classes because it explicitly trains the students on how to write various text-types with their specific content and linguistic features. Hyland (2008) also elaborates that its instructional materials address the needs of the learners in writing different texts.

Using Genre-based Approach, the following are the eight main text-types: description provides information about a person, place, or thing; information report states factual information; procedure tells how to do something; recount expresses what happened; explanation discusses why or how something happens; narrative tells a story; response analyzes a literary text; and expository texts presents or argues a viewpoint (Derewianka, 2003).

\section{Hyland's Framework for Abstract Analysis}

Ken Hyland (2000) has developed a framework in writing a research abstract, namely: introduction (M1), purpose (M2), method (M3), product (M4), and conclusion (M5). The introduction (M1) discusses the background of the research; the purpose (M2) highlights the objectives of the study; the method (M3) displays the design, process, approach, and data; 
product (M4) explains the results of the study; and conclusion (M5) states the implications of the findings of the study (Hyland, 2000).

\section{Methodology}

\section{Research Design}

This study used content analysis because it intensively described and interpreted how CMU undergraduate students used language in writing their research abstracts.

\section{Sampling Procedure}

This study used stratified random sampling in selecting the samples for the study.

\section{The Corpus of the Study}

The corpora of the study were the research abstracts written by CMU undergraduate students in the Academic Year (AY) 2011-2015. The researcher grouped the theses according to college, namely: Agriculture, Arts And Sciences, Engineering, Forestry and Environmental Science, Human Ecology, Nursing, and Veterinary Medicine.

\section{Data Gathering Procedure}

In order to have access to the research abstracts, the researcher wrote a letter of request to Dr. Maria Luisa R. Soliven, the CMU President, Dr. Luzviminda T. Simborio, the CMU VicePresident for Research and Extension, and Dr. Maria Estela B. Detalla, the CMU Director of Research, to allow the researcher to photocopy the research abstracts of the CMU undergraduate theses in the CMU Main Library. After getting the approval, the researcher sent an informed consent to the authors of the undergraduate thesis via e-mail before their theses were included in the analysis.

\section{Method of Analysis}

The researcher analysed the research abstracts using Genre-based Approach and Hyland's Framework for Abstract Analysis (2000) to determine the pattern of the rhetorical moves, obligatory and optional moves, and linguistic features as found in the research abstracts of CMU undergraduate students.

\section{Ethical Considerations}

The study considered the confidentiality and anonymity of the owners/writers of the CMU undergraduate thesis. Moreover, the results of the study would not bear ethical implications regarding the CMU undergraduate students and the quality of their thesis.

\section{Results and Discussions}

\section{Pattern of the Rhetorical Moves in the CMU Research Abstracts}

Based on the analysis of the 305 research abstracts written by CMU undergraduate students, the M2-M3-M4-M5 (purpose-method-product-conclusion) pattern got the highest number of occurrences with 159 or 52.13\%, followed by M2-M3-M4-M5-M6 (purpose-method-productconclusion-recommendation) pattern with 84 or 27.54\%, and M2-M3-M4 (purpose-methodproduct) pattern with 31 or 10.16\%. The patterns M2-M3-M2-M3-M4-M5-M6 (purposemethod-purpose-method-product-conclusion-recommendation), M1-M2-M3-M4-M5-M6 (introduction-purpose-method-product-conclusion-recommendation), M1-M2-M3-M4-M5 (introduction-purpose-method-product-conclusion), M2-M3-M4-M6 (purpose-methodproduct-recommendation), M1-M2-M3-M4 (introduction-purpose-method-product), M3-M2- 
M4 (method-purpose-product) occurred five times or 1.64\%. Lastly, M3-M2-M4-M5 (method-purpose-product-conclusion) pattern occurred once or $0.33 \%$. The students used these patterns as mandated in their College Thesis Manual or by their thesis advisers and the members of the thesis advisory committee.

With 159 out of 305 samples that used M2-M3-M4-M5 (purpose-method-product-conclusion) pattern, the result indicates that these students considered a pattern that began with the objectives of the study, followed by the methodology, then the findings of the study, and finally the implications of the results. The result also denotes that the students employed coherence in writing the information that they conveyed in their research abstracts because the rhetorical moves followed a smooth transition of ideas.

To show a concrete example, sample number 16 indicates that it followed the $M 2-M 3-M 4-M 5$ (purpose-method-product-conclusion) pattern. The abstract began with M2 (purpose) as it presented the general and specific objectives of the study. It is shown in the lines:

The study was conducted to find out the attitude of the students towards the English language. Specifically, it aimed to (1) identify demographic variables which affect the students' attitude towards the English language; (2) determine students' attitude towards English in the class; (3) determine if there is a significant relationship between the students' attitude towards English language and their performance in their English subject.

Then, the research abstract continues with $M 3$ (method) as it presented the respondents of the study, research locale, research design, and statistical treatments used. It is exhibited in the lines:

The respondents of the study were 110 English 15 (Speech Communication) students of CMU in Musuan, Bukidnon. Descriptive statistics was used in the study. Frequency counts, mean, standard deviation, and percentage counting were utilized for the analysis and presentation of the data. The test had a reliability coefficient of 0.52 .

After that, the M4 (results) followed as it presented the results of the data in terms of the attitude of the students towards the English language and the relationship of the variables. It is displayed in the lines:

The data revealed that the students had positive attitude towards the English language. It was found that the demographic profile of the respondents did not affect their attitude towards the English language, but there was a significant relationship between their attitude and their performance in English.

Finally, the research abstract closed with M5 (conclusion) as it presented the inference of the findings of the study. It is revealed in the lines:

It can be inferred from the results of the study that there is a need to develop the positive attitude of the students towards English.

The result of the study is congruent with the studies of Yun (2011), Fan-ping (2011), and Samraj (2000) because the previous studies found an M2-M3-M4-M5 (purpose-methodproduct-conclusion) pattern.

Furthermore, there are also research abstracts that include additional information, specifically the recommendations of the study. For example, sample number 227 ends with: 
It was then recommended that metacognitive strategies awareness, extrinsic and intrinsic motivation should be targeted and cultivated to English language learners to become more efficient to a good performance of the students. Also, audio-visual material was efficient to a good performance to the students. Lastly, further research is invited to investigate other strategies and factors affecting the listening performance of the students.

Based on the analysis of the 305 research abstracts, the result implies that $300 \mathrm{CMU}$ undergraduate students lack the awareness of the standard format in writing research abstracts because they lack the $M 1$ (introduction), exclude some important rhetorical moves in writing their research abstracts, and insert an additional rhetorical move (M6 or recommendation) based on the results of the pattern of the rhetorical moves.

Table 1: Summary of the Rhetorical Move Patterns

\begin{tabular}{llll}
\hline Rhetorical Move Patterns & Frequency & $\begin{array}{l}\text { Percentage } \\
\text { Distribution }\end{array}$ & Rank \\
\hline M2-M3-M4-M5 & 159 & $52.13 \%$ & 1 \\
M2-M3-M4-M5-M6 & 84 & $27.54 \%$ & 2 \\
M2-M3-M4 & 31 & $10.16 \%$ & 3 \\
M2-M3-M2-M3-M4-M5-M6 & 5 & $1.64 \%$ & 4 \\
M1-M2-M3-M4-M5-M6 & 5 & $1.64 \%$ & 4 \\
M1-M2-M3-M4-M5 & 5 & $1.64 \%$ & 4 \\
M2-M3-M4-M6 & 5 & $1.64 \%$ & 4 \\
M1-M2-M3-M4 & 5 & $1.64 \%$ & 4 \\
M3-M2-M4 & 5 & $1.64 \%$ & 4 \\
M3-M2-M4-M5 & 1 & $0.33 \%$ & 5 \\
\hline
\end{tabular}

Obligatory and Optional Moves in the CMU Research Abstracts

Based on the analysis of the 305 research abstracts written by CMU undergraduate students, purpose (M2), method (M3), and product (M4) were the obligatory moves because these rhetorical moves appeared in all of the samples. On the other hand, introduction (M1), conclusion (M5), and recommendation (M6) were the optional moves, where introduction (M1) occurred 18 times or $4.92 \%$, conclusion (M5) with 259 or $84.92 \%$, and recommendation (M6) with 99 or $32.46 \%$.

The result of the obligatory and optional moves agrees with the study of Yun (2011) because purpose (M2), method (M3), and product (M4) were found to be obligatory moves while introduction (M1) and conclusion (M5) were the optional moves, with recommendation (M6) as an additional optional move in the present study. However, it disagrees with the study of Fan-ping (2011) because the previous study found that the only optional move was background (M1) while the rest of the four moves were obligatory moves.

Based on the analysis of the 305 research abstracts, the result implies that the objectives, the methodology, and the findings of the study are the critical information to be included in writing the research abstracts in CMU because these rhetorical moves occurred in all of the samples across disciplines. 
Table 2: Obligatory and Optional Moves in the CMU Research Abstracts

\begin{tabular}{llll}
\hline Rhetorical Moves & Frequency & Percentage Distribution & Classification \\
\hline M1 & 15 & $4.92 \%$ & Optional \\
M2 & 305 & $100.00 \%$ & Obligatory \\
M3 & 305 & $100.00 \%$ & Obligatory \\
M4 & 305 & $100.00 \%$ & Obligatory \\
M5 & 259 & $84.92 \%$ & Optional \\
M6 & 99 & $32.46 \%$ & Optional \\
\hline
\end{tabular}

\section{Linguistic Features in the CMU Research Abstracts}

\section{Tense of the Verb}

Based on the analysis of the tense of the verb of the 305 sample research abstracts, Table 3 displays that the simple past tense obtained the highest number of occurrence with 3518 or $93.46 \%$, followed by simple present tense with 207 or $5.50 \%$, past perfect tense with 15 or $0.40 \%$, present perfect tense with 11 or $0.29 \%$, simple future tense with 8 or $0.21 \%$, present perfect progressive tense with 3 or $0.08 \%$, and past perfect progressive tense with the least number of occurrence with 2 or $0.05 \%$.

Table 3: Tense of the Verb Used in the CMU Research Abstracts

\begin{tabular}{llll}
\hline Tense of the Verb & Frequency & Percentage Distribution & Rank \\
\hline Simple Past Tense & 3518 & $93.46 \%$ & 1 \\
Simple Present Tense & 207 & $5.50 \%$ & 2 \\
Simple Future Tense & 8 & $0.21 \%$ & 5 \\
Present Perfect Tense & 11 & $0.29 \%$ & 4 \\
Present Perfect Progressive Tense & 3 & $0.08 \%$ & 6 \\
Past Perfect Tense & 15 & $0.40 \%$ & 3 \\
Past Perfect Progressive Tense & 2 & $0.05 \%$ & 7 \\
\hline
\end{tabular}

Sample number 2 reveals that it used simple past tense in its different rhetorical moves with the verbs were used, was conducted, was laid, showed, obtained, did, were recorded, was exhibited, got, was observed, exhibited, and had.

Table 4: Tense of the Verb in Sample Number 2

\begin{tabular}{|c|c|c|c|}
\hline $\begin{array}{l}\text { Sentence } \\
\text { Number }\end{array}$ & Content & Verb & $\begin{array}{l}\text { Tense of } \\
\text { the Verb }\end{array}$ \\
\hline S1 & $\begin{array}{l}\text { Five different variety of sweet sorghum were used to } \\
\text { conduct the following objectives: (1) To assess the } \\
\text { percentage incidence per plant and per liner meter and } \\
\text { severity of three (3) identify the diseases; (2) To determine } \\
\text { the host reaction applied with Funguran-OH on three } \\
\text { identified diseases and; (3) To assess biomass yield and } \\
\text { juice yield of sweet sorghum varieties. }\end{array}$ & were used & $\begin{array}{l}\text { simple } \\
\text { past }\end{array}$ \\
\hline S2 & $\begin{array}{l}\text { The study was conducted to evaluate the five varieties } \\
\text { applied with Funguran-OH against the } 3 \text { major diseases of } \\
\text { sweet sorghum during wet season on the month of August } \\
\text { to December } 2010 \text {. }\end{array}$ & $\begin{array}{l}\text { was } \\
\text { conducted }\end{array}$ & $\begin{array}{l}\text { simple } \\
\text { past }\end{array}$ \\
\hline S3 & $\begin{array}{l}\text { It was laid out in Randomized Complete Block Design } \\
\text { (RCBD) with } 4 \text { replications. }\end{array}$ & was laid & $\begin{array}{l}\text { simple } \\
\text { past }\end{array}$ \\
\hline S4 & It was conducted at the Agricultural Experiment Station at & was & simple \\
\hline
\end{tabular}


S5

Central Mindanao University, Musuan, Bukidnon.

The results showed that out of the varieties, $\mathrm{V}_{1}$ (SPV 422), $\mathrm{V}_{2}$ (ICSR 93034), $\mathrm{V}^{3}$ (NTJ2), $\mathrm{V}_{4}$ (ICSV 700), and $\mathrm{V}_{5}$ (ICSV 93046) consistently and significantly obtained a high percent infection in three consecutive disease ratings.

S6

Application of the fungicide did not significantly affect the severity of the disease assessed.

S7 Three major diseases of sweet sorghum were recorded at various stages of growth.

S8 The highest percent incidence was exhibited by leaf rust (Puccinia sp.) in V1 (SPV 422) while V4 (ICSV 700) got the lowest percent incidence in per plant and per linear meter basis.

S9

Anthracnose leaf spot (Colletrotrichum sp.) was observed highest in $\mathrm{V}_{4}$ (ICSV 700), while $\mathrm{V}_{3}$ (NTJ 2) got the lowest percent infection in terms of per plant and per linear meter basis.

S10 Variety 1 (SPV 422) exhibited the highest percent infection caused by Curvulria sp. while $\mathrm{V}_{4}$ (ICSV 700) had the lowest percent incidence and severity based on per plant and per linear meter assessment.

\section{conducted past \\ showed, simple \\ obtained past}

did simple

past

were simple

recorded past

was simple

exhibited, past

got

was simple

observed, past

got

exhibited, simple

had past

The result could be attributed to the fact that these studies were conducted in the past. The CMU undergraduate students used the narrative structure using the simple past tense that stated actions that were done in the past (Rosenwasser \& Stephen, 2015; Celce-Murcia \& Larsen-Freeman, 2010). Furthermore, it can be noted that they also used different verb tenses that affected the consistency of their verb tense.

\section{Voice of the Verb}

Based on the analysis of the voice of the verb, Table 5 demonstrates that the active voice got the highest number of occurrences with 1478 or $39.27 \%$, followed by passive voice with 1297 or $34.46 \%$, and no voice with 989 or $26.28 \%$.

Table 5: Voice of the Verb Used in the CMU Research Abstracts

\begin{tabular}{llll}
\hline Voice of the Verb & Frequency & Percentage Distribution & Rank \\
\hline Active Voice & 1478 & $39.27 \%$ & 1 \\
Passive Voice & 1297 & $34.46 \%$ & 2 \\
No Voice & 989 & $26.28 \%$ & 3 \\
\hline
\end{tabular}

Sample number 38 displays that it contained 12 verbs in the active voice using the words examined, analyzed, was conducted, were, have been residing, have, show, showed, was supported, remained, revealed, perceived, had been changing, instigate, cultivated, are, was, engaged, raised, indicates, is, agreed, and were brought.

Table 6: Voice of the Verb in Sample Number 38

\begin{tabular}{llll}
\hline $\begin{array}{l}\text { Sentence } \\
\text { Number }\end{array}$ & Content & Verb & \multicolumn{2}{l}{$\begin{array}{l}\text { Voice of } \\
\text { the Verb }\end{array}$} \\
\hline S1 & This study examined the perception and coping examined & active \\
& mechanisms of farmers of Barangay San Roque, & voice \\
& Quezon, Bukidnon on climate variability and climate
\end{tabular}


change.

The paper also analyzed the climatic characteristics of the study site using data generated by the nearest

analyzed PAGASA Agromet Station in CMU.

S3 The study was conducted from June to October 2011.
Most of the farmer-respondents were males, 49-57 years old, married, and Roman Catholics.

Most of them have been residing in the area for at least 47 years with 26-30 years of farming experience.

They mostly have 1-4 hectares owned/titled farm planted with corn, vegetables, sugarcane, banana and trees such as Gmelina and Ipil-Ipil generating a monthly income of Php 5,001-10,000.

Using the 40-year climatic data obtained from CMU Agro-Meteorological Station from 1967 to 2006, results show that rainfall has no definite pattern with the highest $(3,069.2 \mathrm{~mm})$ and the lowest $(1,105.0 \mathrm{~mm})$ rainfall values recorded in 1971 and 1991, respectively.

Using trend line analysis, temperature in the site showed an increase from 1967 to 2006 of $97^{\circ} \mathrm{C}, 0.16^{\circ} \mathrm{C}$ and $0.76^{\circ} \mathrm{C}$ for maximum, minimum, and mean air temperature, respectively.

The finding was supported by the perceived change in temperature among farmer-respondents with $7.7 \%$ of them in agreement although $84.6 \%$ remained uncertain.

Findings also revealed that farmers in the area perceived that climate, specifically rainfall and temperature, had been changing over the years.

They also perceived that climate change instigate the occurrence of pest and diseases on agricultural crops resulting to shortage on food supply.

To cope with climate variability and climate change, farmers of San Roque cultivated different varieties of crops which are tolerant to drought and shortened cropping period.

Most noticeable finding in the study was that 64 farmers $(98.5 \%)$ engaged in intercropping agriculture with tree crops and raised farm animals.

This indicates that agroforestry is among the common strategies to cope with income shortages due to climate variability and climate change.

About $95 \%$ of the respondents strongly agreed that income shortages were brought about by climate change. $\begin{array}{ll}\text { was } & \text { passive } \\ \text { conducted } & \text { voice } \\ \text { were } & \text { no voice }\end{array}$

have been active residing voice have no voice

show

active

voice

active

voice

was passive

supported, voice,

remained active

voice

$\begin{array}{ll}\text { revealed, } & \text { active } \\ \text { perceived, } & \text { voice }\end{array}$

had been

changing

perceived, active

instigate voice

cultivated, active

voice,

no voice

are

$\begin{array}{ll}\text { was, } & \text { no } \\ & \text { voice, }\end{array}$

engaged, active

raised voice

indicates, active

voice,

is

no voice

active

voice,

were brought passive

voice 
It is also evident that many students used varied voice of the verb in writing their research abstracts that affected the coherence and consistency of the voice of the verb.

\section{Sentence Structure}

In the analysis of the sentence structure, Table 7 shows that simple sentence obtained the highest number of occurrences with 1645 or $54.61 \%$, followed by complex sentence with 954 or $31.67 \%$, compound sentence with 341 or $11.32 \%$, compound-complex sentence with 54 or $1.79 \%$, and sentence fragment with 18 or $0.60 \%$.

Table 7: Sentence Structure Used in the CMU Research Abstracts

\begin{tabular}{llll}
\hline Sentence Structure & Frequency & Percentage Distribution & Rank \\
\hline Simple Sentence & 1645 & $54.61 \%$ & 1 \\
Complex Sentence & 954 & $31.67 \%$ & 2 \\
Compound Sentence & 341 & $11.32 \%$ & 3 \\
Compound-Complex Sentence & 54 & $1.79 \%$ & 4 \\
Sentence Fragment & 18 & $0.60 \%$ & 5 \\
\hline
\end{tabular}

For instance, sample number 18 employed 15 simple sentences.

Table 8: Sentence Structure in Sample Number 18

\begin{tabular}{|c|c|c|}
\hline $\begin{array}{l}\text { Sentence } \\
\text { Number }\end{array}$ & Content & $\begin{array}{l}\text { Sentence } \\
\text { Structure }\end{array}$ \\
\hline S1 & $\begin{array}{l}\text { This study aimed to determine the significant relationship } \\
\text { between mother's behavior and disruptive behavior and the } \\
\text { significant difference between the disruptive behavior by } \\
\text { parenting style, by marital relation, and by mother's behavior. }\end{array}$ & $\begin{array}{l}\text { Simple } \\
\text { Sentence }\end{array}$ \\
\hline S2 & $\begin{array}{l}\text { This study also aimed to know and evaluate what is the profile of } \\
\text { elementary students with disruptive behavior. }\end{array}$ & $\begin{array}{l}\text { Simple } \\
\text { Sentence }\end{array}$ \\
\hline S3 & A purposive sampling was used to obtain the respondents. & $\begin{array}{l}\text { Simple } \\
\text { Sentence }\end{array}$ \\
\hline S4 & A total of 30 children and 30 mothers were used in the study. & $\begin{array}{l}\text { Simple } \\
\text { Sentence }\end{array}$ \\
\hline S5 & $\begin{array}{l}\text { A Teacher's Report Form and Child Behavioral Checklist was } \\
\text { used to determine the child with disruptive behavior, a researcher } \\
\text { made questionnaire was used to determine the mother's behavior } \\
\text { and an adapted questionnaire was used to determine the } \\
\text { parenting style. }\end{array}$ & $\begin{array}{l}\text { Compound } \\
\text { Sentence }\end{array}$ \\
\hline S6 & $\begin{array}{l}\text { The data was analyzed using the T-test and One Way ANOVA } \\
\text { for the difference and Pearson Product Moment Correlation } \\
\text { Coefficient for the relationship of variables and results revealed } \\
\text { that rule-breaking behavior and mother's behavior showed } \\
\text { significant difference. }\end{array}$ & $\begin{array}{l}\text { Compound } \\
\text { Sentence }\end{array}$ \\
\hline S7 & $\begin{array}{l}\text { On the other hand, there was no significant relationship between } \\
\text { disruptive behavior and parenting style and no significant } \\
\text { difference between disruptive behavior by parenting style and by } \\
\text { marital relation. }\end{array}$ & $\begin{array}{l}\text { Compound } \\
\text { Sentence }\end{array}$ \\
\hline S8 & Significance level was used in the study was set at $p>0.05$. & $\begin{array}{l}\text { Simple } \\
\text { Sentence }\end{array}$ \\
\hline S9 & With the results of the study, it is concluded that a child's & Complex \\
\hline
\end{tabular}




\begin{tabular}{lll}
\hline perception varies. & Sentence \\
S10 & $\begin{array}{l}\text { The child model behavior which they observe from people } \\
\text { around them on how those people set and behave. }\end{array}$ & $\begin{array}{l}\text { Sentence } \\
\text { Fragment }\end{array}$ \\
\hline
\end{tabular}

Overall, the results imply that CMU does not mandate any specific verb tense, verb voice, and sentence structure in writing the research abstracts.

\section{Conclusions}

The following are the implications of the study based on the analysis of the 305 research abstracts written by the CMU undergraduate students:

1. M2-M3-M4-M5 (purpose-method-product-conclusion) pattern got the highest number of occurrences in terms of the rhetorical move pattern in writing research abstracts with 159 or $50.96 \%$;

2. Purpose (M2), method (M3), and product (M4) are the most vital rhetorical moves in writing the research abstracts in CMU because these moves appeared in all of the samples; and

3. CMU does not dictate any specific tense of the verb, voice of the verb, and sentence structure to be used in writing research abstracts.

\section{References}

Bhatia, V. K. (1993). Analysing genre: Language use in professional settings. London: Longman.

Celce-Murcia, M., \& Larsen-Freeman, D. (2010). The grammar book: An ESL/EFL teacher's course. (2nd ed.) Philippines: MG Reprographics.

Derewianka, B. (2003). Trends and issues in genre-based approaches. RELC Journal. Retrieved from http://agusdepe.staff.uns.ac.id/files/2011/09/ trendsnissuesingenrebasedapproach.pdf

Fan-ping, T. (2011). Analyses of move structure and verb tense of research article abstracts in Applied Linguistics Journals. International Journal of English Linguistics, 1 (2), 27 39.

Hyland, K. (2000). Disciplinary discourse: Social interactions in academic writing. London: Longman.

Hyland, K. (2008). Genre and academic writing in the disciplines. Language Teaching. 41 (4): 543-562. Retrieved from http://www2.caes.hku.hk/kenhyland/files/2012/08/Genre-and-academic-writing-inthe-disciplines.pdf

Indiana University. (2010). Writing abstracts. Retrieved from http://www.indiana.edu/ wts/pamphlets/abstracts.shtml

Osman, H. (2004). Genre-based instruction for ESP. Retrieved from http://www.melta.org.my/ET/2004/2004-13.pdf

Rosenwasser, D., \& Stephen, J. (2015). Writing analytically. (7th ed.). USA: Cengage.

Samraj, B. (2005). An exploration of a genre set: Research article abstracts and introduction in two disciplines. English for Specific Purposes, 24 (2), 141-156.

Sidaway, R. (2006). The genre-based approach to teaching writing. Retrieved from http://www.britishcouncil.org/portugal-ie2006s-richard-sidaway.pdf

Swales, J. M., \& Feak, C. B. (2009). Abstracts and the writing of abstracts. Michigan: University of Michigan Press.

The University of Adelaide. (2009). Writing an abstract. Retrieved from http://www.adelaide.edu.au/writingcentre/learning_guides/learningGuide_writingAnA bstract.pdf 
The University of Melbourne (n.d.) Writing an abstract: Understanding and developing abstracts. Retrieved from http://services.unimelb.edu.au/_data/assets/pdf_file/ 0007/471274/Writing_an_Abstract_Update_051112.pdf

Yun, L. (2011). A genre analysis of English and Chinese research article abstracts in linguistics and chemistry (Unpublished master's thesis). San Diego State University, USA. Retrieved from http://sdsudspace.calstate.edu/bitstream/handle/ 10211.10/1128/Li_Yun.pdf?sequence=1 